Mongolian Geoscientist

Original article

\title{
Modern glacier dynamics in Mt. Tsambagarav in the Mongolian Altai Mountain Range
}

\author{
Tuyagerel Davaagatan ${ }^{1 *(i D)}$, Alexander Orkhonselenge ${ }^{2(i D}$
}

\footnotetext{
${ }^{I}$ Division of Physical Geography, Institute of Geography and Geoecology, Mongolian Academy of Sciences, Ulaanbaatar 14200, Mongolia

${ }_{2}^{2}$ Laboratory of Geochemistry and Geomorphology, School of Arts and Sciences, National University of Mongolia, Ulaanbaatar 14201, Mongolia

*Corresponding author.Email: dtuyagerel@gmail.com, ORCID: 0000-0002-7537-4539
}

\section{ARTICLE INFO}

Article history:

Received 4 September, 2020

Accepted 6 October, 2020

\begin{abstract}
This study presents the modern glacier dynamics in Mt. Tsambagarav in the Mongolian Altai Mountain Range over the last four decades. This is the first review of this type of glacier dynamics for this massif. Changes in glacier area in Mt. Tsambagarav are estimated using normalized indexes (Normalized Difference Snow Index and Normalized Difference Principal Component Snow Index). Spatial distribution of the modern glaciers delineated with Landsat Multispectral Scanner (MSS: resolution of $80 \mathrm{~m}$ ), Landsat Thematic Mapper (TM: resolution of $30 \mathrm{~m}$ ) and Landsat Operational Land Imager (OLI: resolution of $30 \mathrm{~m}$ ) imageries. Result shows that Mt. Tsambagarav has lost $51.7 \%$ of the glacier area from $132.24 \mathrm{~km}^{2}$ in 1977 to $63.92 \mathrm{~km}^{2}$ in 2017 . The loss in glacier area for Mt. Tsambagarav during the last 40 years reflect the rapid response of the modern glacier to climate change, i.e., it is highly sensitive to solar insolation and/or rapidly rising local and regional mean annual temperatures. The remote sensing data and field survey suggest that the modern glaciers would be disappeared on a scale of decades. Rapid melting of the glacier in this massif contributes to surface water resources in western Mongolia. This study demonstrates the importance of spatial analysis in the remote area for understanding the context of changes in the modern glaciers.
\end{abstract}

Keywords: Glacier, Surface Water, Change, Landsat

\section{INTRODUCTION}

As an important source of freshwater (e.g., Brown, 2000; Yang et al., 2003; Zhou and Li, 2003), estimating glacier dynamics on high mountains is crucial for understanding and hypothesizing local and regional hydrological cycles. Climate change can modulate water resources through altering glacier mass balances (Liu et al., 2015). Changes in modern glaciers in the Mongolian Altai Mountain Range are an important component of the hydrological balance in the watersheds in western Mongolia (Orkhonselenge and Harbor, 2018).

Globally, glaciers have been abruptly melting due to climate change in recent years. According to Beniston and Rebetez (1996), environmental changes in high-latitude and high-altitude regions are prone to cryospheric changes such as

(C) The Author(s). 2020 Open access This article is distributed under the terms of the Creative Commons Attribution 4.0 International License (https://creativecommons.org/licenses/by/4.0/), which permits unrestricted use, distribution, and reproduction in any medium, provided you give appropriate credit to the original author(s) and source, provide a link to the Creative Commons license, and indicate if changes were made. 
reductions of snow-covered areas due to global warming. This process is not being away from the high mountains in Mongolia lying on the high-latitudes. For instance, an area of the maximum glaciers in the Mongolian Altai Mountain Range during the Pleistocene decreased from $62900 \mathrm{~km}^{2}$ to only $1100 \mathrm{~km}^{2}$ (Orkhonselenge and Harbor, 2018).

High mountains in Mongolia were glaciated twice in the early and late Pleistocene (Tsegmid, 1969) due to uplifts during the new tectonic activities in the late Neogene and the early Quaternary periods (Jigj, 1976; Sanjmyatav, 2009). Glaciers in Mongolia were initially noted by Russian tourists and scientists since 1870 s and they were scientifically studied since 1921 (Tsegmid, 1969). The dominant style of glaciation recorded in Mongolia is valley glaciers including hanging glaciers (Tsegmid, 1969) and alpine-style glaciations in the Mongolian Altai Mountain Range (e.g., Lehmkuhl et al., 2004; Blomdin et al., 2016). Paleoglacial landforms, including ice caps, valley glaciers, hanging glaciers, cirques, hummocky terrain, moraines and morainedammed lakes, are widespread in the Mongolian Altai, Khangai, Khentii and Khuvsgul Mountain Ranges.

Recent studies show that modern glaciers occupy small areas in these mountain ranges (Blomdin et al., 2016) and play a vital role in water resources in Central Asia (Orkhonselenge and Harbor, 2018). The glaciated areas have been decreasing rapidly in recent years (e.g., Davaa, 2010; Kamp et al., 2013; Orkhonselenge, 2016). The modern glaciers in Mongolia constitute over $70 \%$ of freshwater resources (Davaa, 2010) and/or water resources of $19.4 \mathrm{~km}^{3}$ (Davaa, 2015), however the glacier areas rapidly decrease over the last half-century. Reviewing spatial and temporal patterns of modern glaciers is important not only to contribute to knowledge about how glaciers respond to climate change, but also to hypothesize the social, economic and ecological development in the region that depends heavily on glacial meltwater to sustain water supplies for agriculture and human consumption.

Here we infer glacier dynamics in Mt. Tsambagarav in the Mongolian Altai Mountain
Range during the last 40 years. For extensive investigations on glaciers in Mt. Tsambagarav there are still ongoing disagreements about the frequency, number and extension of paleoglaciers and modern glaciers. Previous studies on Mt. Tsambagarav have used a Normalized Difference Snow Index (NDSI) and Landsat 5 and 7 images. In this study we present precise data obtained from two different indexes and Landsat 5 and 8 images. To advance the knowledge on the modern glacier in this massif, we estimated and compiled the changes in area of the modern glacier in Mt. Tsambagarav in 1977, 1991, 2002 and 2017 based on NDSI, Normalized Difference Principal Component Snow Index (NDPCSI) and Landsat images. In this context, there are no previously published maps with these indexes and recent satellite data for this mountain massif.

\section{GEOGRAPHICAL SETTING}

The Mongolian Altai Mountain Range extends over $1000 \mathrm{~km}$ from Mt. Tavan Bogd (4374 m a.s.l) in the northwest to Gichgene Mountain Range in the southeast (Murzaev, 1952) and it covers an area of over $248900 \mathrm{~km}^{2}$. There are numerous branch and isolated mountains elevated over $4000 \mathrm{~m}$ a.s.l. with paleoglaciers and modern glaciers in the Mongolian Altai such as Mt. Munkh Khairkhan (4231 m a.s.1.), Mt. Sutai (4226 m a.s.1.), Mt. Tsast Bogd (4208 $\mathrm{m}$ a.s.1.), Mt. Bugat (4041 m a.s.1.), Mt. Kharkhiraa (4040 m a.s.1), Mt. Ikh Turgen (4030 $\mathrm{m}$ a.s.1) and Mt. Turgen (4029 $\mathrm{m}$ a.s.1). The dominant mountains in the Mongolian Altai consist of dislocated Precambrian stratigraphic sequences during the late Neogene and the early Quaternary (Tsegmid, 1969).

Mt. Tsambagarav, elevated at $4008 \mathrm{~m}$ a.s.l., is an isolated mountain in the east of the Mongolian Altai Mountain Range in western Mongolia (Fig. 1). This massif is surrounded by the high mountains in the west and the Depression of Great Lakes in the east, i.e., it lies at the easternmost edge of the Mongolian Altai (Fig. 1). Glacier in Mt. Tsambagarav constitutes a part of remnants of a large former paleoglacier that covered the great part of the Mongolian Altai during the Pleistocene, i.e., it is one of mountains covered with paleoglaciers and 


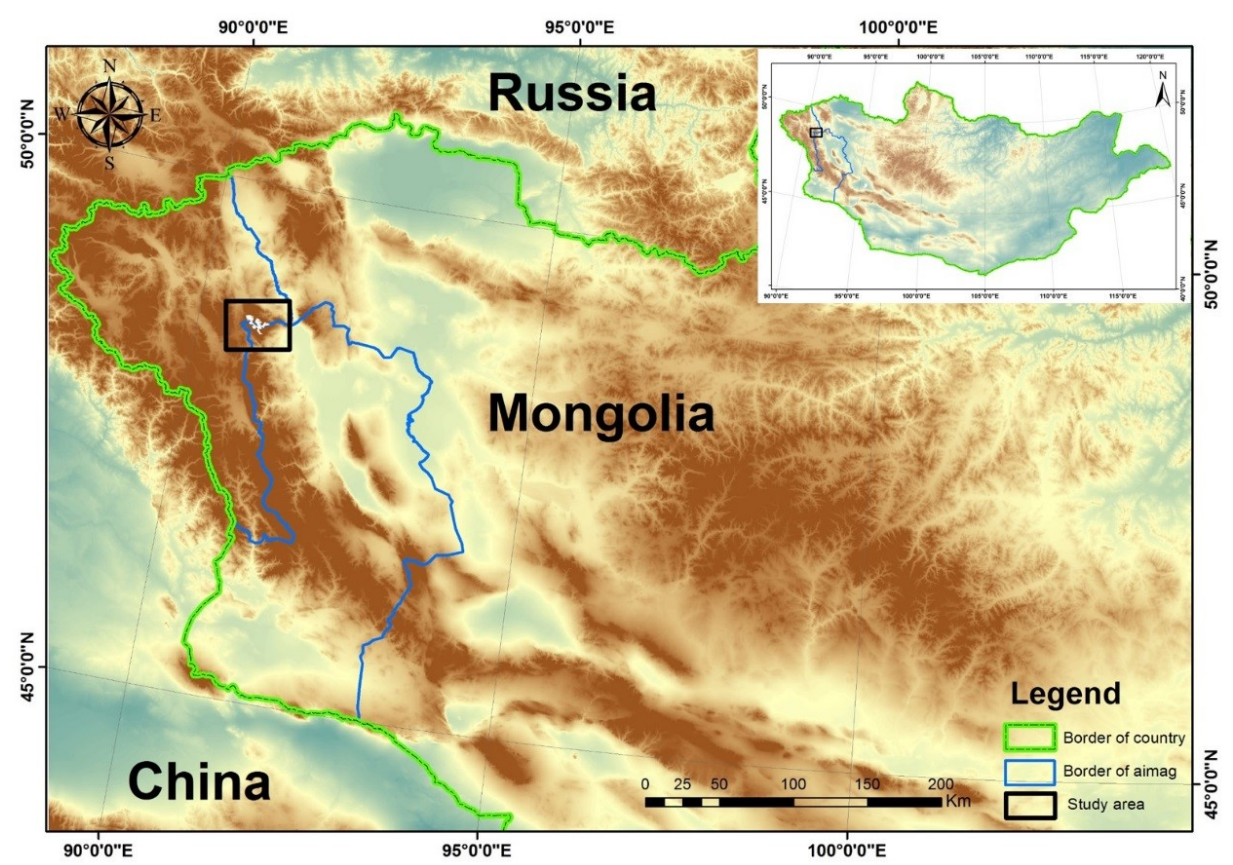

Fig. 1. Geographical location of Mt. Tsambagarav in the Mongolian Altai Mountain Range in western Mongolia.

modern glaciers.

The modern glacier and moraines in Mt. Tsambagarav are shown in Fig. 2. The modern glacier in Mt. Tsambagarav is considered as an erosional surface glacier among the three types of modern glaciers in Mongolia of (1) mountain -slope glaciers of $75.2 \%$ (cirques, hanging cirques and hanging), (2) valley glaciers of $21 \%$ (depression, cirque valley and hanging valley) and (3) erosional surface glaciers of $3.8 \%$ (degraded flat peaks) (Davaa and Oyunbaatar, 2012).

Mt. Tsambagarav receives a maximum annual precipitation of $300-350 \mathrm{~mm}$ and it constitutes

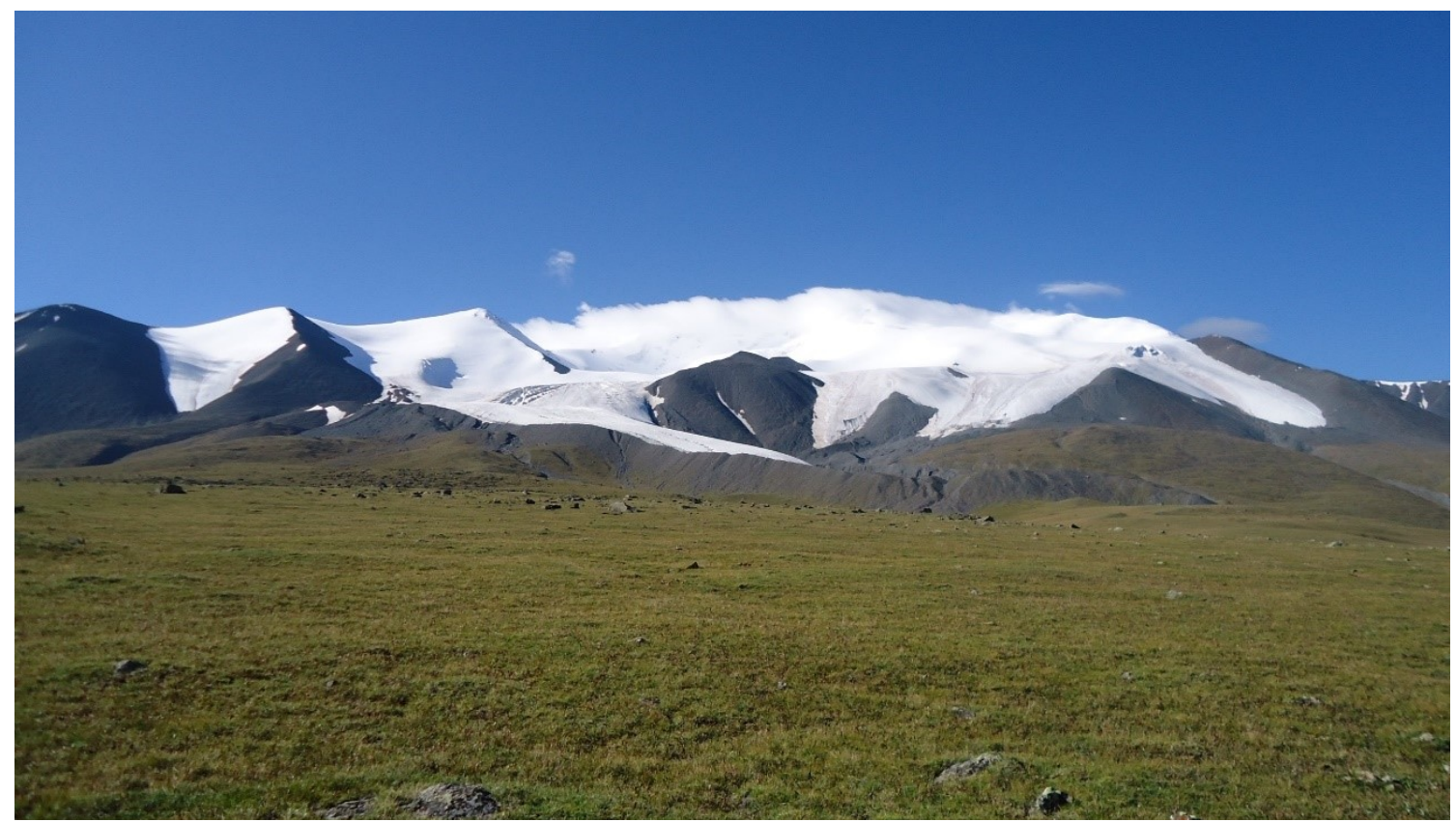

Fig. 2. A view of the modern glacier on southwestern slope of Mt. Tsambagarav. Photo by A. Orkhonselenge on 08.10.2013. 
one of the glaciated mountains recharging surface water in western Mongolia. The modern glacier in Mt. Tsambagarav feeds rivers draining into Khovd River (Myagmarsuren and Namkhai, 2015). According to the Khovd meteorological station, lying at $88 \mathrm{~km}$ southeast of the mountain, annual average air temperature is $1.8^{\circ} \mathrm{C}$ with monthly average temperatures of $19^{\circ} \mathrm{C}$ in summer and $-25.5^{\circ} \mathrm{C}$ in winter, and annual average precipitation is $210 \mathrm{~mm}$.

\section{METHODS}

This study focuses on precise estimation and delineation of the modern glacier dynamics in Mt. Tsambagarav. In calculation of glacier area, Landsat imagery data, NDSI, Snow Grain Size Index (SGSI), Normalized Difference Snow Thermal Index (NDSTI) and NDPCSI are broadly used today. In the estimation of the glacier dynamics in Mt. Tsambagarav, two indexes of NDSI and NDPCSI are used.

Firstly, NDSI is a useful tool to differentiate periods with and without snow and to clarify clouds, snow and glacier (Negi et al., 2009). An advantage of NDSI is that it is based on landform changes and it is able to detect snow on mountain shadow (Kulkarni et al., 2002). NDSI value ranges from -1 to 1 , and values more than 0.4 are taken into account as glaciated area. NDSI is indicated with an equation (Eq. 1) formulated by Hall et al. (1995), Xiao et al. (2002) and Kulkarni et al. (2006).

$$
N D S I=\frac{\text { band }_{\text {green }}-\text { band }_{\text {swir }}}{\text { band }_{\text {green }}+\text { band }_{\text {swir }}}
$$

Secondly, NDPCSI is more advanced than NDSI because of its direct detection of glaciated areas. In the estimation of NDPCSI, removing areas of lakes and rivers is not required. Then the glaciated areas are compiled after reclassifying raster data and picking pixels up with values more than 0.4. With NDPCSI, Principal Component Analysis (PCA) allows us to understand multiple scale data of abrasion and accumulation zones. Determining which wavelength is important to consider the glaciated areas is required (Pope and Rees, 2014). The PCA was used to determine changes in area of the modern glacier in Mt. Tsambagarav depending on climatic factors. In calculation of NDPCSI based on an equation (Eq. 2), channels 1 (PC 1: brightest) and 6 (PC 6: darkest) of Landsat image were taken into account (Fig. 3). PC 1 reflects snow albedo, while PC 6 shows snow absorption (Sibandze et al., 2014).

$$
\text { NDPCSI }=\frac{P C_{\text {brightest }}-P C_{\text {darkest }}}{P C_{\text {brightest }}+P C_{\text {darkest }}}
$$

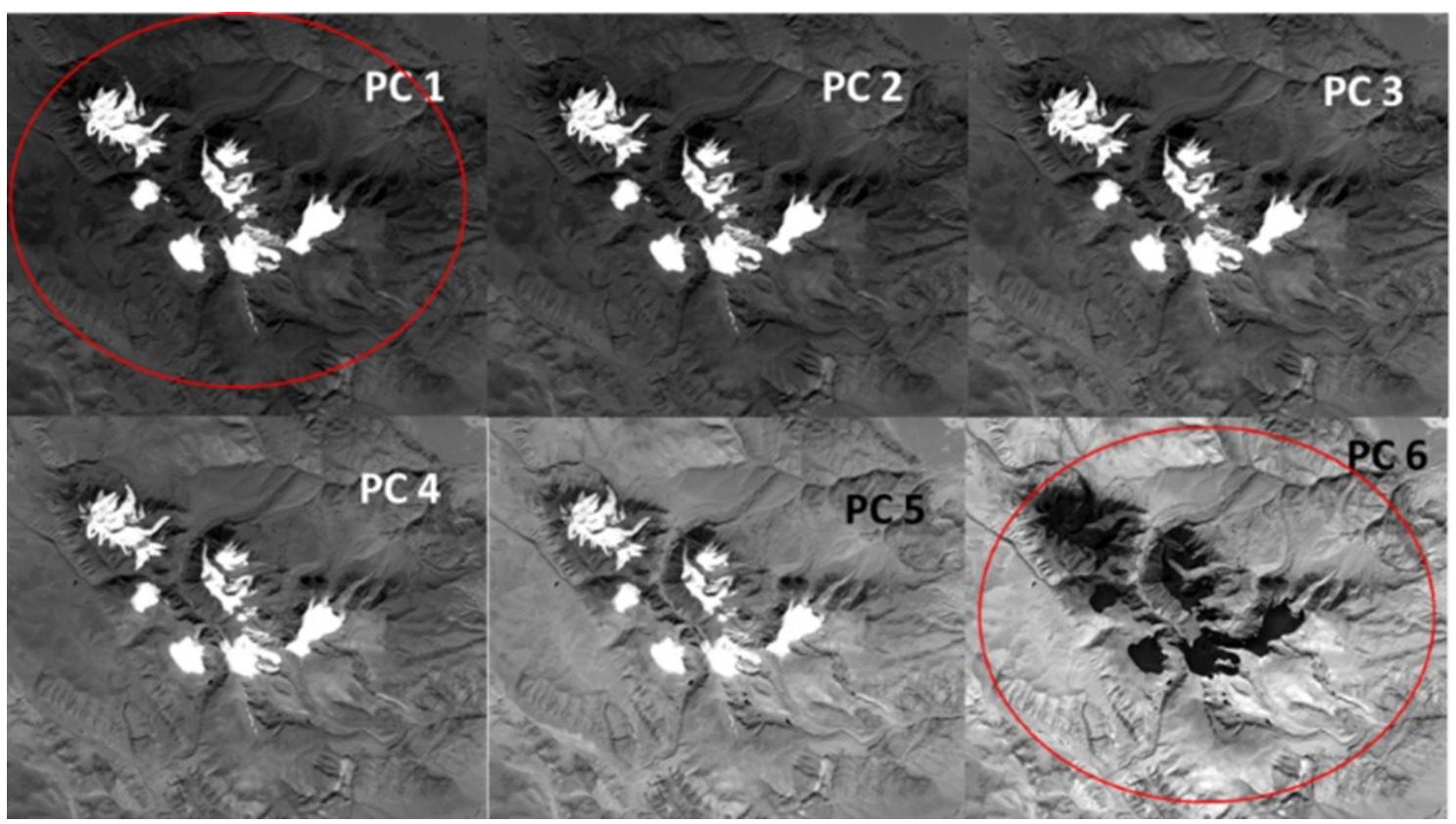

Fig. 3. Maps from channel PC 1 to channel PC 6 of Landsat data showing the areas of modern glacier in Mt. Tsambagarav based on NDPCSI: Source data on 09.17.2017. 
In delineation showing spatial distribution of the modern glaciers (Fig. 4) medium-resolution satellite imagery data with a low percentage of clouds on Landsat Multispectral Scanner with resolution of $80 \mathrm{~m}$ (MSS: 08.13.1977), Landsat Thematic Mapper with resolution of $30 \mathrm{~m}$ (TM: 08.09.1991; 09.17.2002) and Landsat Operational Land Imager with resolution of 30 m (OLI: 09.17.2017) are applied.

\section{RESULTS}

The modern glacier extents in Mt. Tsambagarav are spatially estimated in 1977, 1991, 2002 and 2017 using Landsat, NDSI and NDPCSI. The result shows instructive difference between the two indexes. NDSI indicates the glaciated areas more in detail than other landforms. However, for specters, the NDSI is not good at recognizing high resolution of shallow water body and differentiating the glaciers from other objects. Whereas NDPCSI shows the glaciated areas directly without any requirement of additional steps to remove areas of lakes and rivers (Fig. 3), i.e., it is much efficient to compile the glaciated areas based on Landsat imagery data.

Area of the modern glacier in Mt. Tsambagarav decreased from $132.24 \mathrm{~km}^{2}$ in 1977 to 8.473 $\mathrm{km}^{2}$ in 1991, $72.04 \mathrm{~km}^{2}$ in 2002 and $63.92 \mathrm{~km}^{2}$ in 2017 (Tables 1, 2; Figs. 4, 5). The area of the modern glacier in Mt. Tsambagarav was lost by $35.9 \%\left(47.51 \mathrm{~km}^{2}\right)$ between 1977 and 1991, $9.7 \%\left(12.69 \mathrm{~km}^{2}\right)$ between 1991 and 2002, and $6.1 \%\left(8.12 \mathrm{~km}^{2}\right.$ ) between 2002 and 2017 (Table 1). In total, the modern glacier area has been lost by $51.7 \%\left(68.32 \mathrm{~km}^{2}\right)$ during the last 40 years from 1977 to 2017 (Table 1; Fig. 5).

\section{DISCUSSIONS}

The changes in the spatial distribution of the modern glacier in Mt. Tsambagarav during the last four decades indicate the alpine glaciers advanced in the past and rapid retreats of the modern glaciers in the last half-century (Fig. 5). The area of the modern glacier in Mt. Tsambagarav has significantly decreased over the last seven decades (Table 2). Our result is comparable to other works in Mt. Tsambagarav
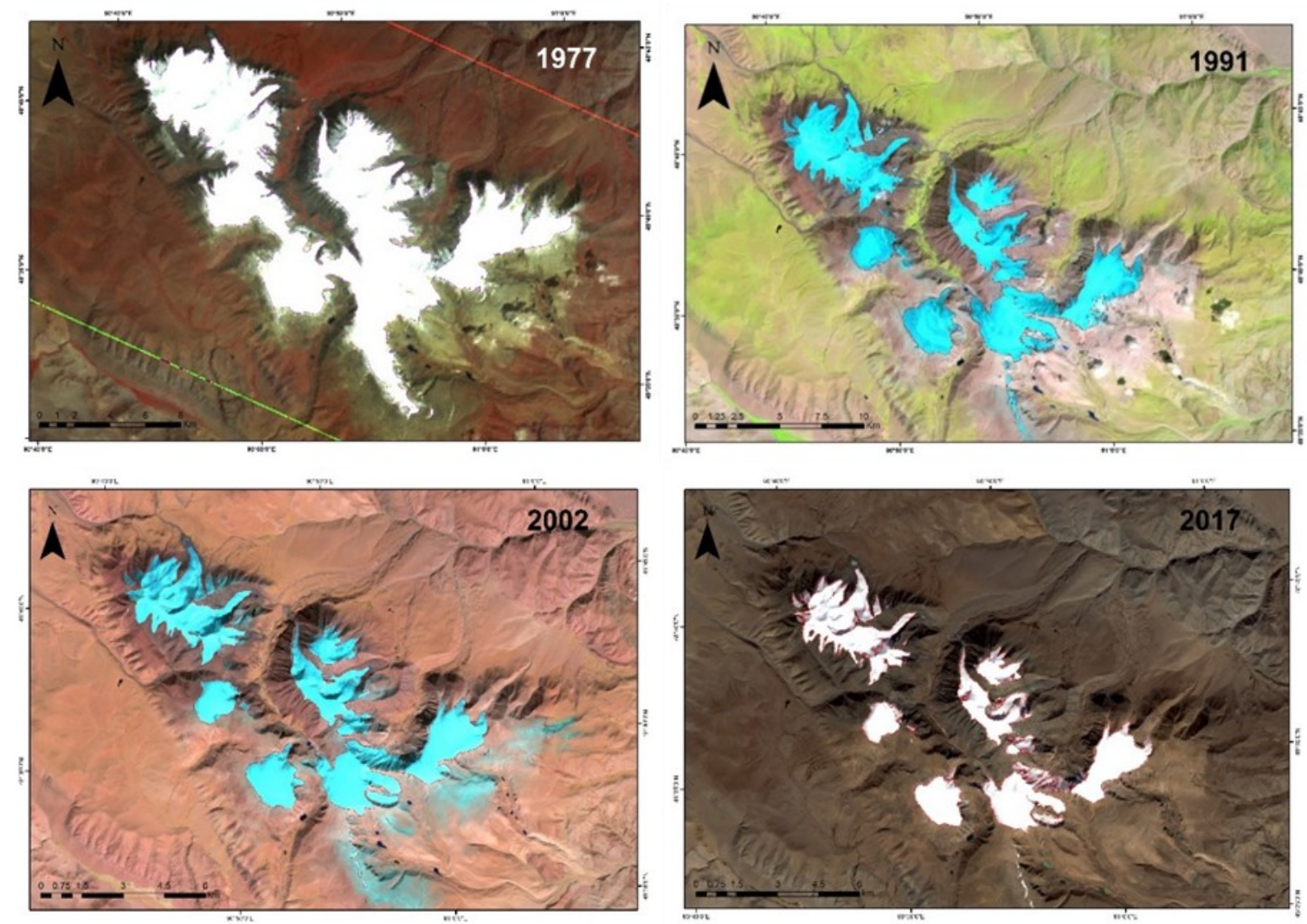

Fig. 4. Spatial distribution of modern glaciers in Mt. Tsambagarav in 1977, 1991, 2002 and 2017. 
(Table 2) and it is relatively consistent with those estimated by Erdenetuya et al. (2006) and Kadota and Davaa (2007). For instance, the glacier area of $71.52 \mathrm{~km}^{2}$ in 2002 estimated by Erdenetuya et al. (2006) was quite close to our result in the year, although the authors used different Landsat imagery data (Table 2). These studies in 1991 and 1992 used Landsat 5

Table 1. Decreased area of the modern glacier in Mt. Tsambagarav.

\begin{tabular}{ccccc}
\hline No & Year & $\begin{array}{c}\text { Duration } \\
(\mathrm{yr})\end{array}$ & $\begin{array}{c}\text { Loss of } \\
\text { glacier } \\
\text { area }\left(\mathrm{km}^{2}\right)\end{array}$ & $\begin{array}{c}\text { Per- } \\
\text { cent }\end{array}$ \\
\hline 1 & $1977-1991$ & 14 & 47.51 & 35.9 \\
2 & $1991-2002$ & 11 & 12.69 & 9.7 \\
3 & $2002-2017$ & 15 & 8.12 & 6.1 \\
\hline & $1977-2017$ & 40 & 68.32 & 51.7 \\
\hline
\end{tabular}

imagery data, however there was a gap between the estimations (Table 2). The continuous trend in decrease of the modern glacier area in Mt. Tsambagarav may have been impacted by climate change with rising temperature and falling precipitation. In Mongolia, average air temperature has risen by $2.24^{\circ} \mathrm{C}$, while average precipitation has dropped by $7.3 \%$ over the last 70 years since 1940s (Batima et al., 2005). The climate change in Mongolia has been reflected in increase of mean annual air and soil temperatures, decline in duration of rainfall, rapid melting of glaciers and permafrost, and strengthening evaporation and desertification.

The spatial analysis of the modern glacier in Mt. Tsambagarav coincides with that resulted from other high mountains in the Mongolian Altai Mountain Range. Recent studies (e.g., Kamp et al., 2013) show that current climate change takes a pronounced effect on present-day glaciers in Mongolia. For example, in the northeastern part

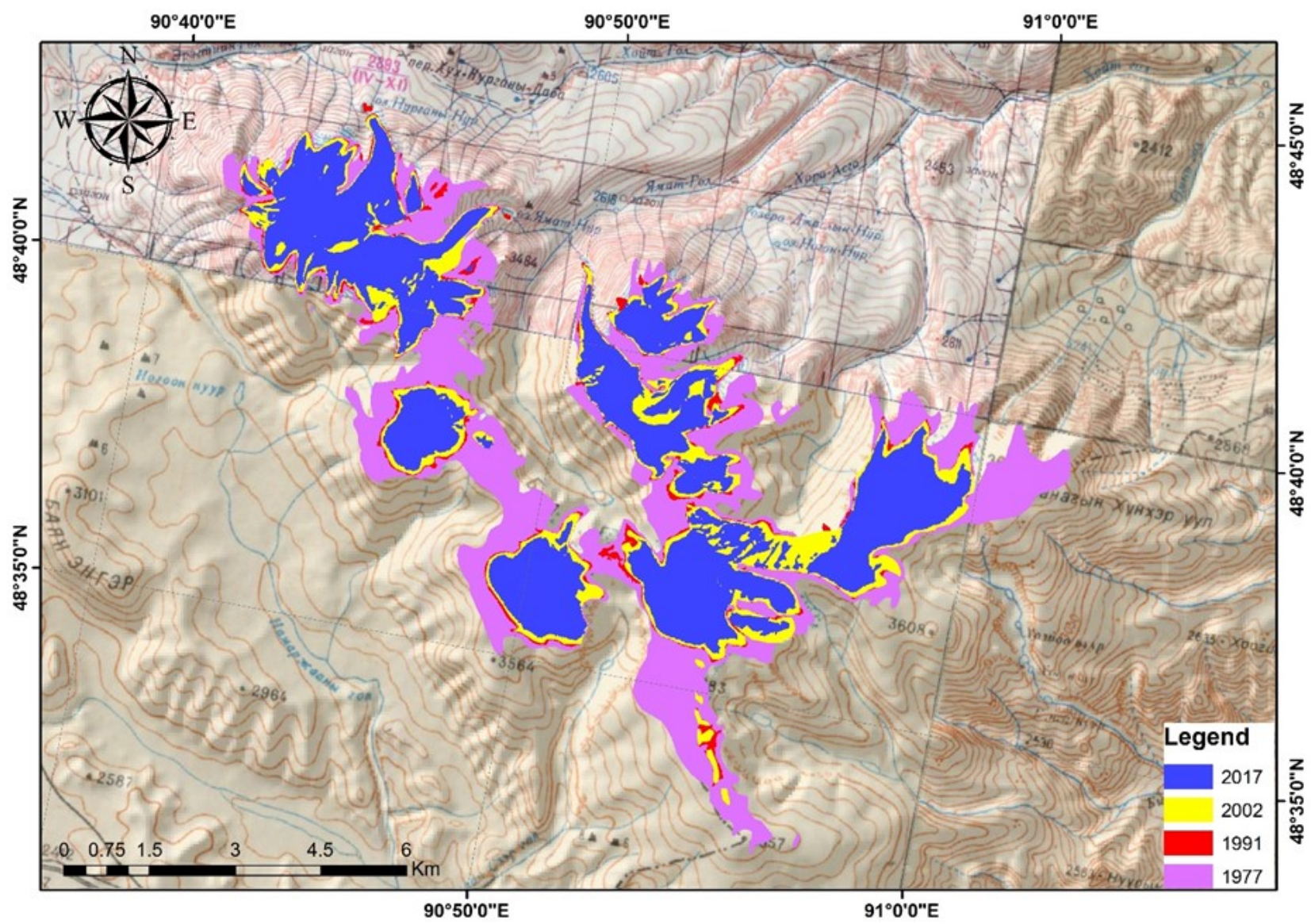

Fig. 5. Changes in extended area of the modern glacier in Mt. Tsambagarav in 1977-2017. 
Table 2. Changes in area of the modern glacier in Mt. Tsambagarav over the last seven decades

\begin{tabular}{cccl}
\hline Data source & Year & Area $\left(\mathrm{km}^{2}\right)$ & \multicolumn{1}{c}{ References } \\
\hline Topo map & 1940 & 105.09 & Erdenetuya et al., 2006 \\
Landsat 1 & 1977 & 132.24 & This study \\
Landsat 5 & 1991 & 84.73 & This study \\
Landsat 5 & 1992 & 90.98 & Erdenetuya et al., 2006 \\
Landsat 7 & 2000 & 74.08 & Erdenetuya et al., 2006 \\
Landsat 7 & 2000 & 74.08 & Kadota and Davaa, 2007 \\
Landsat 7 & 2002 & 71.52 & Erdenetuya et al., 2006 \\
Landsat 5 & 2002 & 72.04 & This study \\
Landsat 8 & 2017 & 63.92 & This study \\
\hline
\end{tabular}

of the Mongolian Altai, Lehmkuhl (2012) identified glacier retreat by 75-79 $\mathrm{m}$ for toe-tosummit of snowline altitudes between the Little Ice Age (LIA) limits and positions in 1948 and 1991. Moreover, the modern glaciers in the Mongolian Altai as a whole have shrunk in size by $22 \%$ during the past $50-60$ years (Davaa, 2010).

Furthermore, Lehmkuhl et al. (2004) reconstructed the Equilibrium Line Altitudes (ELAs) located at around $3000 \mathrm{~m}$ a.s.1. in the northeastern and $3700 \mathrm{~m}$ a.s.l. in the southeastern mountains in the Mongolian Altai. Orkhonselenge and Harbor (2018) noted that Mt. Ikh Turgen in the Mongolian Altai lost $45.6 \%$ of its total glacier area between 1970 $\left(41.4 \mathrm{~km}^{2}\right)$ and $2011\left(18.9 \mathrm{~km}^{2}\right)$ and the ELA of the glaciers retreated in elevation by $98 \mathrm{~m}$ on north and $144 \mathrm{~m}$ on south aspects. This study in Mt. Tsambagarav demonstrates the trend in decrease in area of the modern glaciers in the Mongolian Altai Mountain Range.

\section{CONCLUSIONS}

The area of the modern glacier in Mt. Tsambagarav in the Mongolian Altai Mountain Range in western Mongolia is reviewed in 1977, 1991, 2002 and 2017 using NDSI, NDPCSI and Landsat data. During the last 40 years the Mt. Tsambagarav has lost about $\sim 52 \%$ of its modern glacier. The continuous trend in decrease of the modern glacier in Mt. Tsambagarav over the last seven decades coincided with those resulted from high mountains in the Mongolian Altai, which may have been related to impact of global warming. For further estimation of the impact of climate change on the modern glaciers, detailed field survey and geochronological analysis are required to check the spatial analysis presented in this study. Such work allows us to gain the complete understanding of response of the modern glacier in the high mountains of Mongolia to the climate and other controlling drivers.

\section{ACKNOWLEDGEMENTS}

We would like to thank MSc. Ts.Batnyam from Division of Physical Geography, Institute of Geography and Geoecology, Mongolian Academy of Sciences for helping calculation of a new index.

\section{REFERENCES}

Batima, P., Natsagdorj, L., Gomboluudev, P., Erdenetsetseg, B. 2005. Observed Climate Change in Mongolia: AIACC Working Paper, v. 12,26 p.

Beniston, M., Rebetez, M. 1996. Regional behaviour of minimum temperatures in Switzerland for the period 1979-1993: Theoretical Applied Climatology, v. 55(3/4), p. 231-243. https://doi.org/10.1007/BF00871739

Blomdin, R., Heyman, J., Stroeven, A.P., Hattestrand, C., Harbor, J.M., Gribenski, N., Jansson, K.N., Petrakov, D.A., Ivanov, M.N., Orkhonselenge, A., Rudoy, A.N., Walther, M. 2016. Glacial Geomorphology of the Altai and Western Sayan Mountains, Central Asia: Journal of Maps, v. 12(1), p. 123-136. https:// doi.org/10.1080/17445647.2014.992177 
Brown, R.D. 2000. Northern Hemisphere snow cover variability and change: 1915-1997: Journal of Climate, v. 13, p. 2339-2355. https://doi.org/10.1175/1520-0442(2000) $013<2339:$ NHSCVA $>2.0 . \mathrm{CO} ; 2$

Davaa, G. 2010. Climate Change Impacts on Water Resources in Mongolia: Integration of Climate Change Adaptation into Sustainable Development in Mongolia, Institute for Global Environmental Strategies (IGES), Proceedings, p. 30-36.

Davaa, G. 2015. Surface water of Mongolia: Ulaanbaatar, 202 p. (In Mongolian)

Davaa, G., Oyunbaatar, D. 2012. Surface water resources assessment. In: Gantuul, Sh. (Ed.), Integrated Water Management National Assessment Report, v. I. Government of Mongolia, Ministry of Environment and Green Development, Ulaanbaatar, p. 9-75.

Erdenetuya, M., Khishigsuren, P., Davaa, G., Otgontugs, M. 2006. Glacier change estimation using Landsat TM data: International Archives of the Photogrammetry, Remote Sensing and Spatial Information Science, v. 36(6), p. 242.

Hall, D.K., Foster, J.L., Chien, J.L., Riggs, G.A. 1995. Determination of actual snow-covered area using Landsat TM and digital elevation model data in Glacier National Park, Montana: Polar Record, v. 31(177), p. 191198. https://doi.org/10.1017/S0032247400013693

Jigj, S. 1976. Brief Description of Paleoglaciations and Paleoglaciers: Ulaanbaatar, 51 p. (In Mongolian)

Kadota, T., Davaa, G. 2007. Recent glacier variations in Mongolia: Annals of Glaciology, p. 185-188. https://doi.org/10.3189/172756407782871675

Kamp, U., McManigal, K.G., Dashtseren, A., Walther, M. 2013. Documenting glacial changes between 1910, 1970, 1992 and 2010 in the Turgen Mountains, Mongolian Altai, using repeat photographs, topographic maps, and satellite imagery: The Geographical Journal, v. 179(3), p. 248-263. https:// doi.org/10.1111/j.1475-4959.2012.00486.x

Kulkarni, A.V., Srinivasulu, J., Manjul, S.S., Mathur, P. 2002. Field based spectral reflectance studies to develop NDSI method for snow cover monitoring: Journal of the Indian Society of Remote Sensing, v. 30(1-2), p. 73-80. https://doi.org/10.1007/BF02989978

Kulkarni, A.V., Singh, S.K., Mathur, P., Mishra, V.D. 2006. Algorithm to monitor snow cover using AwiFs data of RESOURCESAT-1 for the Himalayan region: International Journal of Remote Sensing, v. 27 (12), p. 2449-2457. https://doi.org/10.1080/01431160500497820

Lehmkuhl, F. 2012. Holocene glaciers in the Mongolian Altai: an example from the Turgen -Kharkhiraa Mountains: Journal of Asian Earth Sciences, v. 52, p. 12-20. https:// doi.org/10.1016/j.jseaes.2011.11.027

Lehmkuhl, F., Klinge, M., Stauch, G. 2004. The extent of Late Pleistocene glaciations in the Altai and Khangai Mountains: In Ehlers J. and Gibbard P.L. (Eds.), Quaternary Glaciations Extent and Chronology, Part III, p. 243-454, Amsterdam: Elsevier. https://doi.org/10.1016/ $\underline{\text { S1571-0866(04)80130-1 }}$

Liu, Y., Wu, J., Liu, Y., Hu, B.X., Hao Y, Huo, X., Fan, Y., Yeh, T.J., Wang, Z.L. 2015. Analyzing effects of climate change on streamflow in a glacier mountain catchment using an ARMA model: Quaternary International, v. 358, p. 137-145. https:// doi.org/10.1016/j.quaint.2014.10.001

Murzaev, E.M. 1952. The description of Physical Geography of Mongolia: Moscow. (In Russian)

Myagmarsuren, D., Namkhai, A. 2015. Protected areas of Mongolia: Ulaanbaatar, 87 p. (In Mongolian)

Negi, H.S., Kulkarni, A.V., Semwal, B.S. 2009. Estimation of snow cover distribution in Beas basin, Indian Himalaya using satellite data and ground measurements: Journal of Earth System Science, v. 118(5), p. 525. https:// doi.org/10.1007/s12040-009-0039-0

Orkhonselenge, A. 2016. Glacial Geomorphology of Mt. Munkh Saridag in the Khuvsgul Mountain Range, Northern Mongolia: Géomorphologie: relief, processus, environnement, v. 22(4), p. 389-398. https:// doi.org/10.4000/geomorphologie.11596

Orkhonselenge, A., Harbor, J.M. 2018. Impacts of Modern Glacier Changes on Surface Water Resources in Western and Northern Mongolia: Journal of Water Resource and Protection, 10 (6), p. 559-576. https:// doi.org/10.4236/jwarp.2018.106031

Pope, A., Rees, W.G. 2014. Impact of spectral, 
and radiometric properties of multispectral imagers on glacier surface classification: Remote Sensing of Environment, v. 141, p. 113. https://doi.org/10.1016/j.rse.2013.08.028

Sanjmyatav, Z. 2009. Physical Geography of Mongolia: Ulaanbaatar, 34 p. (In Mongolian)

Sibandze, P., Mhangara, P., Odindi, J., Kganyago, M. 2014. A comparison of Normalised Difference Snow Index (NDSI) and Normalised Difference Principal Component Snow Index (NDPCSI) techniques in distinguishing snow from related land cover types: South African Journal of Geomatics, v. 3(2), p. 197-206. https://doi.org/10.4314/sajg.v3i2.6

Tsegmid, Sh. 1969. Physical Geography of Mongolia: Ulaanbaatar, 405 p. (In Mongolian)
Xiao, X., Moore, B., Qin, X., Shen, Z., Boles, S. 2002. Large-scale observations of alpine snow and ice cover in Asia: Using multi-temporal VEGETATION sensor data: International Journal of Remote Sensing, v. 23(11), p. 2213 -2228 . https://doi.org/10.1080/01431160110076180

Yang, D., Robinson, D., Zhao, Y., Estilow, T., Ye, B. 2003. Streamflow response to seasonal snow cover extent changes in large Siberian watersheds: Journal of Geophysics Research, v. 108 , p. 4578.

https://doi.org/10.1029/2002JD003149

Zhou, X., Li, S. 2003. Comparison between in situ and MODIS-derived spectral reflectances of snow and sea ice in the Amundsensea, Antarctica: International Journal of Remote Sensing, v. 24(24), p. 5011-5032. https:// doi.org/10.1080/0143116031000070346 